\title{
Reporting of adverse reactions to benznidazole: does medical expertise matter?
}

\author{
Ana Cristina Pereiro, ${ }^{1}$ Mabel Lenardón, ${ }^{2}$ Alejandro Zeballos, ${ }^{2}$ Marina Chopita, ${ }^{2}$ \\ Marcelo Abril, ${ }^{1}$ and Silvia Gold ${ }^{1}$
}

Suggested citation Pereiro AC, Lenardón M, Zeballos A, Chopita M, Abril M, Gold S. Reporting of adverse reactions to benznidazole: does medical expertise matter? Rev Panam Salud Publica. 2018;42:e69. https://doi. org/10.26633/RPSP.2018.69

ABSTRACT This study evaluated and compared follow-up and adverse drug reaction (ADR) reporting for Chagas disease (CD) patients treated with benznidazole (BZN) by two health teams with different levels of experience, using medical records for 204 patients participating in the first year of a scaled-up public health program for CD case detection and treatment conducted at all 46 primary health care centers in La Plata district, Buenos Aires, Argentina, in 2014. Both teams were experienced in CD patient management and trained in BZN administration, and included senior physicians, but one team had no experience in administering BZN while the other team had three years of experience due to their participation in the program's pilot project. Patients with positive serology for CD were treated with $5 \mathrm{mg} / \mathrm{kg}^{\prime}$ day of BZN for 60 days. Patients' median age was 35 years and $84.3 \%$ were female. There was a statistically significant difference in the number of ADRs reported by the experienced versus the inexperienced health teams (18 versus 44 respectively; $\mathrm{P}<0.001$ ). Health team experience in administering $B Z N$ to $C D$ patients, and treatment duration, were significantly associated with reporting of ADRs (adjusted odds ratios (aORs) 0.340 (95\% confidence interval (CI): 0.177-0.652) and 0.967 (CI: 0.942-0.993) respectively). ADR reporting increased with patient age, occurring at the highest frequency $(42.9 \%)$ in people $50+$ years old. All treatment discontinuations (nine) occurred in patients followed up by the inexperienced health team. Level of experience in BZN administration to CD patients was significantly and inversely associated with frequency of $A D R$ reports: inexperienced health team members tended to report more.

Keywords Chagas disease; primary health care; drug-related side effects and adverse reactions; public health; Argentina; Latin America.

Chagas disease (CD), caused by the protozoan parasite Trypanosoma cruzi, was first described in 1909 (1, 2). CD remains a serious public health problem

\footnotetext{
Fundación Mundo Sano, Buenos Aires, BA, Argentina. Send correspondence to: Ana Cristina Pereiro, apereiro@mundosano.org

2 Secretaría de Salud, La Plata, BA, Argentina.
}

in Latin America and is currently the leading cause of sudden death, severe cardiac arrhythmias, and intractable hearth failure in the region $(3,4)$. In Argentina, about 1.6 million people are infected with the disease, with an estimated prevalence rate of 4.1 (5).

For more than three decades, only two drugs (nifurtimox and benznidazole
$(\mathrm{BZN}))$ have been available and proved effective for the treatment of T. cruzi infections $(4,6)$. Though both drugs are associated with a high frequency of adverse drug reactions (ADRs) $(6,7), \mathrm{BZN}$ is the preferred drug in Argentina (8). The incidence of ADRs during treatment with $\mathrm{BZN}$ increases with patient age, with $41.1 \%$ of ADRs occurring in CD pediatric 
patients 10 days to 19 years old (9) versus $57.1 \%-87.5 \%$ in CD patients $16-58$ years old $(10,11)$. When administered during the acute phase of CD, BZN has a parasitological cure rate of nearly $80 \%(12,13)$. Though its therapeutic indication in the chronic phase is still debated, in the absence of advanced Chagas cardiomyopathy, some experts recommend BZN treatment for chronic CD adults $(3,6)$.

The acute phase of $\mathrm{CD}$ is usually asymptomatic $(6,14)$, with the majority of cases progressing to a chronic phase without injury (clinically evident disease) $(6,8)$. Only $20 \%-30 \%$ of chronic CD patients develop clinically evident disease, which most commonly affects the heart in a process that may last years, or decades (6). Thus, most chagasic patients are not aware of their status and may remain infected for life $(6,14)$.

Active search for positive cases using laboratory serologic testing is of utmost importance for detection of CD (15), and patient access to anti-trypanosomal drugs and specialized clinical expertise is essential for appropriate disease management (6). CD patient treatment and follow-up should be performed mainly at the first level of care, as recommended by the Pan American Health Organization (PAHO) (16) and the Ministry of Health of Argentina (8).

From 2010 to 2013, a pilot project focusing on early diagnosis and timely treatment of $\mathrm{CD}$ was conducted at three primary health care centers (PHCCs) in an area of La Plata district, a non-endemic city, with no vectors, in Buenos Aires Province, Argentina (15). A total of 181 individuals presenting positive serology for $C D$ were identified and treated during the pilot, with the number of diagnoses increasing each year (15). The encouraging results obtained in this project, and the need to strengthen primary care to improve prevention and treatment in CD patients, encouraged local health authorities to expand the pilottested methodology to all 46 PHCCs in La Plata in a scaled-up public health CD intervention program conducted in 2014.

Both health teams responsible for patient follow-up and assessment and reporting of ADRs for the 2014 CD intervention program were experienced in $C D$ patient management (patient classification, patient selection for BZN treatment, and recommended hygienic and dietary practices during treatment), but one team had no experience in BZN administration while the other team had three years of experience due to their participation in the program's pilot project. Both teams were trained in BZN administration and included senior physicians. The study reported here was conducted after one year of implementation of the program. The aim of the study was to evaluate and compare follow-up and ADR reporting for CD patients treated with BZN by two health teams with different levels of experience in BZN administration.

\section{MATERIALS AND METHODS}

\section{Design and population}

This retrospective follow-up study was based on medical records from the first year of the $\mathrm{CD}$ intervention program. The research met criteria for an exception to the informed consent requirement according to the "Guide for Investigations of Human Health" published by Argentina's Ministry of Health (items A3b and B1.1.5b) (17)) and thus did not require an ethics review. The study complied with Declaration of Helsinki ethical principles for medical research involving human subjects, and all required measures for guaranteeing anonymity, including the use of numbers to identify patient data.

The program methodology was based on the one used during the 2010-2013 pilot project (15). Its main features included training health team members (physicians, nurses, midwives, and social workers) at the participating PHCCs in $C D$ diagnosis and treatment, and reinforcing routine and systematic $C D$ serology testing (enzyme-linked immunosorbent assay (ELISA) and hemagglutination inhibition (HAI)) for all pregnant women attending the PHCCs. Children whose mothers were diagnosed with CD were also tested. Although the methodology prioritized the detection and inclusion of pregnant women and children, no age or gender restrictions were defined.

All patients with positive serology for CD, except pregnant women and patients with contraindications according to the treatment guidelines (8), were prescribed parasiticide treatment with BZN for 60 days, taking $5 \mathrm{mg} / \mathrm{kg} /$ day to a maximum dose of $400 \mathrm{mg}$. Patients were contacted for weekly appointments during the first month of treatment to refill BZN and detect ADRs. The visits were made fortnightly during the second month. All ADRs registered by the patients or observed by the health team members were reported, regardless of clinical significance ("minor," "moderate," or "serious"). A "serious" adverse event or reaction was any untoward medical occurrence that at any dose could result in death/ be life-threatening and/or require inpatient hospitalization and/or result in persistence of significant disability or incapacity. "Moderate" adverse reactions/events were those that required suspending daily activities and/or antihistamine or corticoid treatment, and "minor" adverse reactions/ events were those that were reported in a standard questionnaire from the regulatory agency during the study but were not mentioned by the patient to the health providers and did not require treatment. No serious adverse reactions or events were reported in the study.

\section{Information collected}

The following variables were collected for patients with positive serology for $\mathrm{CD}$ who were treated and followed during the first year of the program: baseline demographic and anthropometric characteristics (age, gender, and weight); proportion of women who were lactating; proportion of women who were using contraceptives; proportion of patients/ women who were using concomitant medication; and BZN treatment information (dose, duration, suspension, and reported ADRs).

\section{Statistical analysis}

Quantitative variables were reported as means, medians, and minimums/ maximums. Qualitative variables were reported as counts and percentages.

Bivariate analyses were conducted for patient and treatment independent variables (age, gender, weight, proportion of lactating women, proportion of women using contraceptives, use of concomitant medication, BZN dose, and treatment duration) to compare the patients followed by the experienced and inexperienced health teams.

Pearson's chi-squared and MannWhitney $U$ tests were performed to evaluate the association between the report of ADRs and categorical and continuous variables respectively.

Binomial logistic regressions were performed to identify the variables 
significantly and independently associated with the report of ADRs. As two independent variables (proportion of lactating women and proportion of women using contraceptives) are only applicable to female gender patients, two binomial logistic regressions were performed: one considering male and female patients and all independent variables except the proportions of lactating women and women using contraceptives, and the other considering female patients only and all independent variables except gender. Adjusted odds ratios (aORs) and their respective $95 \%$ confidence intervals (CIs) were also estimated.

All statistical tests were two-tailed, considered 5\% statistically significant, and used $95 \%$ CIs whenever applicable. Statistical analyses were performed using IBM $^{\circledR}$ SPSS $^{\circledast}$, version 19.0 (IBM Corp., Armonk, NY, USA).

\section{RESULTS}

\section{Patient and treatment characterization}

Data for 204 patients with positive serology for CD during the first year of the program were included in the study. Of those, 99 patients were followed at PHCCs that had participated in the pilot project and 105 were followed at additional PHCCs added to the coverage of the scaled-up intervention program. The majority of patients were female $(84.3 \%)$, median age was 35 years (range: 3-64), and median weight was $66 \mathrm{~kg}$ (range: 11.5-125).

Baseline demographic and anthropometric characteristics (gender, age, and weight) and the proportion of patients using concomitant medication did not differ significantly between patients evaluated by the two health teams (Table 1). The proportion of lactating women and women using contraceptives were significantly higher in female patients evaluated by the experienced health team compared to those evaluated by the health team with no previous experience (13.1\% versus $2.3 \%$ and $20.2 \%$ versus $4.5 \%$ respectively). No statistically significant differences were observed between the two health team groups for BZN dose or treatment duration.

\section{ADR reporting}

A total of 62 ADRs were reported during the first year of the program's

TABLE 1. Characteristics of Chagas disease (CD) patients treated with benznidazole (BZN) $(n=204)$, by type of health team (experienced versus inexperienced), La Plata, Buenos Aires, Argentina, 2014-2015

\begin{tabular}{lccc}
\hline CD patient characteristic & $\begin{array}{c}\text { Health team with experience } \\
\text { in BZN administration to } \\
\text { CD patients } \\
(\text { No. }=99)\end{array}$ & $\begin{array}{c}\text { Health team with no } \\
\text { previous experience in BZN } \\
\text { administration to CD patients } \\
(\text { No. = 105) }\end{array}$ & $P$ \\
\hline Male (\%) & $15(15.2)$ & $17(16.2)$ & $0.838^{\mathrm{a}}$ \\
Median age in years (min-max $)$ & $34(3-52)$ & $36(4-64)$ & $0.159^{\mathrm{c}}$ \\
Median weight in kg (min-max) & $65.0(13.0-100.0)$ & $68.0(11.5-125.0)$ & $0.155^{\mathrm{d}}$ \\
Using concomitant medication (\%) & $9(9.1)$ & $5(4.8)$ & $0.222^{\mathrm{a}}$ \\
Lactating female (\%) & $11(13.1)$ & $2(2.3)$ & $0.007^{\mathrm{a}}$ \\
Female using contraceptives (\%) & $17(20.2)$ & $4(4.5)$ & $0.002^{\mathrm{a}}$ \\
Median BZN dose in mg (min-max) & $325.0(60.0-400.0)$ & $349.0(50.0-450.0)$ & $0.066^{\mathrm{d}}$ \\
Median BZN treatment duration in & $60.0(30.0-60.0)$ & $60.0(9.0-60.0)$ & $0.068^{\mathrm{d}}$ \\
days (min-max) & & & \\
\hline Source: Prepared by the authors based
\end{tabular}

Source: Prepared by the authors based on the study results.

a Pearson's chi-squared test.

${ }^{\mathrm{b}}$ Min-max: minimum-maximum.

${ }^{\mathrm{c}} t$-test for equality of means.

${ }^{\mathrm{d}}$ Mann-Whitney $U$ test for independent samples.

implementation, categorized as follows: dermatitis and pruritus, 31; gastrointestinal disturbances, 12; headache and nausea, 6; muscular pains, 5; other, 8 . Of these, 18 were reported by the health team with previous experience in $\mathrm{BZN}$ administration to $\mathrm{CD}$ patients and 44 were reported by the health team with no previous experience. This difference was statistically significant $(P<0.001)$. No serious ADRs were reported.

\section{Factors associated with the ADR reports}

Bivariate analyses between each independent variable and the report of ADRs (Table 2) demonstrated that the experience of the health team members in BZN administration to $C D$ patients and the treatment duration were significantly associated with the report of ADRs when considering both genders as well as female patients only.

The results of the two binomial logistic regressions conducted for both male and female patients and female patients only are summarized in Table 3 . The backward elimination process was used in both logistic regressions: all independent variables (except the proportion of lactating women and women using contraceptives, when considering both male and female patients, and the gender variable, when considering female patients only) were initially entered in the models, and each one was sequentially deleted if it did not contribute to the regression equation (i.e., if it was not statistically significant).

Based on the logistic regressions results for the model, considering both genders, the experience of the health team members in BZN administration to $\mathrm{CD}$ patients and the treatment duration were the only variables significantly associated with the report of ADRs (aOR: 0.340 (CI: 0.177-0.652) and aOR: 0.967 (CI: 0.942-0.993) respectively). Similarly, the same variables were significantly associated with the report of ADRs in the logistic regression model considering female patients only (aOR: 0.252 (CI: 0.121-0.527) and aOR: 0.969 (CI: 0.943$0.996)$ respectively).

Goodness-of-fit-tests (HosmerLemeshow) demonstrated good performance for the model considering both genders and the model considering female patients only $(P=0.338$ and $P=0.230$ respectively).

\section{ADR reporting frequency}

The frequency of ADR reporting by age group is shown in Table 4. Report of an ADR increased with patient age so was most frequent for people more than 50 years old, with $42.9 \%$ of this age group having an ADR report.

\section{Treatment suspension}

A total of nine patients, all followed by the health team with no previous experience in BZN administration to $C D$ 
TABLE 2. Characteristics of Chagas disease (CD) patients treated with benznidazole (BZN) $(n=204)$ that appear to be associated with reporting of adverse drug reactions (ADRs), La Plata, Buenos Aires, Argentina, 2014-2015

\begin{tabular}{|c|c|c|c|}
\hline Characteristic & $\begin{array}{l}\text { ADR report } \\
\text { (No. }=62 \text { ) }\end{array}$ & $\begin{array}{l}\text { No ADR report } \\
\text { (No. }=142 \text { ) }\end{array}$ & $P$ \\
\hline \multicolumn{4}{|l|}{ All patients } \\
\hline \multicolumn{4}{|l|}{ Gender (\%) } \\
\hline Male & $10(16.1)$ & $22(15.5)$ & $0.909^{\mathrm{a}}$ \\
\hline Female & $52(83.9)$ & $120(84.5)$ & \\
\hline Median age in years $\left(\min -\max ^{b}\right)$ & $36.5(6.0-56.0)$ & $34.0(3.0-64.0)$ & $0.164^{c}$ \\
\hline Median weight in kg (min-max) & $67.5(22.0-97.0)$ & $66.0(11.5-125.0)$ & $0.312^{c}$ \\
\hline Median BZN dose in mg (min-max) & $350(100.0-450.0)$ & $325(50.0-400.0)$ & $0.229^{c}$ \\
\hline Median BZN treatment duration in days (min-max) & $60(9.0-60.0)$ & $60(15.0-60.0)$ & $0.045^{c}$ \\
\hline \multicolumn{4}{|l|}{ Using concomitant medication (\%) } \\
\hline Yes & $60(96.8)$ & $130(91.5)$ & $0.175^{\mathrm{a}}$ \\
\hline No & $2(3.2)$ & $12(8.5)$ & \\
\hline \multicolumn{4}{|l|}{$\begin{array}{l}\text { Health team with experience in BZN administration } \\
\text { to CD patients (\%) }\end{array}$} \\
\hline Yes & $18(29.0)$ & $81(57.0)$ & $<0.001^{\mathrm{a}}$ \\
\hline No & $44(71.0)$ & $61(43.0)$ & \\
\hline \multicolumn{4}{|l|}{ Female patients only } \\
\hline Median age in years (min-max) & $35.5(6.0-56.0)$ & $34.0(3.0-52.0)$ & $0.137^{c}$ \\
\hline Median weight in $\mathrm{kg}$ (min-max) & $65.5(24.0-97.0)$ & $65.0(11.5-125.0)$ & $0.392^{c}$ \\
\hline Median BZN dose in mg (min-max) & $325.0(122.0-450.0)$ & $325.0(50.0-400.0)$ & $0.352^{c}$ \\
\hline Median BZN treatment duration in days (min-max) & $60.0(9.0-60.0)$ & $60.0(15.0-60.0)$ & $0.044^{c}$ \\
\hline \multicolumn{4}{|l|}{ Using concomitant medication (\%) } \\
\hline Yes & $2(3.8)$ & $10(8.3)$ & $0.289^{a}$ \\
\hline No & $50(96.2)$ & $110(91.7)$ & \\
\hline \multicolumn{4}{|l|}{$\begin{array}{l}\text { Health team with experience in BZN administration } \\
\text { to } C D \text { patients }(\%)\end{array}$} \\
\hline Yes & $13(25.0)$ & $71(59.2)$ & $<0.001^{\circ}$ \\
\hline No & $39(75.0)$ & $49(40.8)$ & \\
\hline \multicolumn{4}{|l|}{ Lactating $(\%)$} \\
\hline Yes & $1(1.9)$ & $12(10.0)$ & $0.066^{\mathrm{a}}$ \\
\hline No & $51(98.1)$ & $108(90.0)$ & \\
\hline \multicolumn{4}{|l|}{ Using contraceptives (\%) } \\
\hline Yes & $5(9.6)$ & $16(13.3)$ & $0.494^{a}$ \\
\hline No & $47(90.4)$ & $104(86.7)$ & \\
\hline
\end{tabular}

Source: Prepared by the authors based on the study results.

a Pearson's chi-squared test.

${ }^{\mathrm{b}}$ Min-max: minimum-maximum.

${ }^{c}$ Mann-Whitney U test.

patients, discontinued BZN treatment. Of these, six patients discontinued it due to ADRs, and three stopped their treatment due to travel reasons.

\section{DISCUSSION}

Argentina has the highest number of people living with CD (in absolute terms). This is an extremely big challenge for the health authorities due to the morbidity and mortality caused by this neglected disease. For decades, a few hospitals in some provinces have provided medical services for people with $C D$, but not enough to satisfy the demand. and treatment at the PHCCs. Both teams had experience in $C D$ patient management, were trained in BZN administration, and included senior physicians. However, only one team had experience in BZN administration to CD patients, having participated in the three-year pilot project for the program; the other team had no experience in BZN administration to $C D$ patients prior to their participation in the second, scaled-up phase of the study.

The main finding after one year of follow-up was the significantly higher reporting of ADRs by health team members with no previous experience in the treatment of CD patients with BZN compared to health team members with three years of previous experience (44 versus 18 respectively; $P<0.001)$ — quite similar to the situation observed during the first year of the pilot project. This result suggests a possible association between the level of therapeutic experience with BZN in the management of $C D$ and the reporting of ADRs. While providing training to the health team members during the pilot project, it was observed that although they were knowledgeable about CD, they had no previous experience with $B Z N$, and the initial fears of ADRs were relatively high (15).

Both teams used the same ADR classification and implemented the same treatment for minor or moderate ADRs. No serious ADRs were registered. The most frequent ADRs were allergic dermatitis and pruritus, and gastrointestinal intolerance, in accordance with the literature (18). The level of experience of the health teams was expected to be the main factor associated with ADR reporting, but other patient- and treatment-related variables may have influenced the incidence of ADRs as well as the reporting of them. These variables include patient demographic and anthropometric characteristics (age, sex, and weight); the proportions of lactating women and women using contraceptives; the use of concomitant medication; and the BZN dose and treatment duration. Of these variables, age has been reported as a factor influencing the frequency and intensity of BZN ADRs, which become more frequent and severe with advancing age $(6,9,19)$, and female sex has been associated with an increased occurrence of BZN ADRs (3).

The logistic regressions confirmed the results obtained in the bivariate analyses 
TABLE 3. Logistic regression models for reporting of adverse drug reactions (ADRs) to benznidazole (BZN) treatment in Chagas disease (CD) patients $(n=204)$, La Plata, Buenos Aires, Argentina, 2014-2015

\begin{tabular}{lccc}
\hline Characteristic & $P$ & $\mathrm{aOR}^{\mathrm{a}}$ & $95 \% \mathrm{Cl}^{\mathrm{b}}$ \\
\hline $\begin{array}{l}\text { All patients } \\
\quad \text { Health team with experience in BZN administration to } \\
\text { CD patients (ref } \mathrm{f}^{\mathrm{a}}=\text { no previous experience) }\end{array}$ & 0.001 & 0.340 & $0.177-0.652$ \\
$\quad \begin{array}{l}\text { BZN treatment duration (days) } \\
\text { Female patients only }\end{array}$ & 0.012 & 0.967 & $0.942-0.993$ \\
$\quad \begin{array}{l}\text { Health team with experience in BZN administration to } \\
\text { CD patients (ref = no previous experience) }\end{array}$ & $<0.001$ & 0.252 & $0.121-0.527$ \\
$\quad$ BZN treatment duration (days) & 0.027 & 0.969 & $0.943-0.996$ \\
\hline
\end{tabular}

Source: Prepared by the authors based on the study results.

a aOR: adjusted odds ratio.

${ }^{\mathrm{b}} \mathrm{Cl}$ : confidence interval.

${ }^{\circ}$ Independent variables included in the analysis for all patients: gender, age (years), weight (kg), BZN dose (mg), BZN treatment duration (days), and use of concomitant medication; variables that did not show statistical significance $(P<0.05)$ for ADR reporting were excluded from the final model.

${ }^{\mathrm{a}}$ Ref: reference.

${ }^{\mathrm{e}}$ Independent variables included in the analysis for female patients only: age (years), weight (kg), BZN dose (mg), BZN treatment duration (days), use of concomitant medication, lactating, and use of contraceptives.

TABLE 4. Frequency of reporting of adverse drug reactions (ADRs) to benznidazole (BZN) treatment in Chagas disease patients $(n=204)$, by age group, La Plata, Buenos Aires, Argentina, 2014-2015

\begin{tabular}{lccc}
\hline Age group (years) & No. of patients & No. of ADRs reported & \% of age group with 6 ADRs reported \\
\hline $0-19$ & 13 & 3 & 23.1 \\
$20-39$ & 128 & 35 & 27.3 \\
$40-50$ & 56 & 21 & 37.5 \\
$>50$ & 7 & 3 & 42.9 \\
\hline
\end{tabular}

Source: Prepared by the authors based on the study results.

for male and female patients and for female patients only: the level of experience of the health team members in BZN administration to $C D$ patients and the BZN treatment duration were significantly associated with the report of ADRs, independent of all variables initially considered in the models. Specifically, for both male and female patients, the experienced health team members had a $66.0 \%$ decreased odds of reporting ADRs compared to inexperienced health team members, and the odds of reporting an ADR decrease by 3.3\% per treatment day. In female patients only, the odds of reporting ADRs by experienced health team members decreased by $74.8 \%$ compared to inexperienced health team members, and the odds of reporting an ADR decreased by $3.1 \%$ per treatment day.

Two main factors related to the lack of previous experience with BZN may explain the higher reporting of ADRs by the inexperienced health team members. First, compared to the experienced health team, these members were more likely to be unfamiliar with certain conditions for which appropriate measures should be adopted prior to the start of BZN treatment. Common examples include obese patients with fatty livers that should first follow a diet to lose weight, and febrile patients, for whom it is recommended to start the treatment only after fever resolution. Second, inexperienced members either lacked knowledge of the hygienic and dietary recommendations that should be followed when considering treatment with BZN, or did not consider them relevant. These included a low-fat and hypoallergenic diet, abstention from alcohol consumption, and avoiding prolonged exposures to the sun (8). As a result, patients followed by the inexperienced team were more likely to have started BZN before the adoption of appropriate measures for relevant comorbidities and to be unaware of the recommendations to be followed during treatment, thus increasing the propensity for developing ADRs. Clinical disorders to be excluded from initial treatment were better fulfilled by the experienced teams.
Although the decreased odds of reporting an ADR per treatment day with a longer treatment duration suggest that variable is associated with reduced reporting of ADRs, it could also be explained by the fact that the majority of treatment discontinuations were due to ADRs. Consequently, shorter treatment periods (due to treatment discontinuations) were associated with a more frequent reporting of ADRs compared to longer periods, which is reflected by a longer treatment duration in patients with no reported ADR compared to patients for which an ADR was reported (median: 60 (15.0-60.0) versus 60 (9.060.0 days); mean: $56.1 \pm 9.0$ versus $50.5 \pm$ 15.6 days respectively).

The patients evaluated by both health teams differed significantly in terms of the proportions of lactating women and women using contraceptives. Despite the possible increased propensity to develop adverse reactions in patients using contraceptives, due to a higher risk of drug interactions, the difference observed between both patient groups is not expected to have been responsible for the higher reporting of ADRs by the inexperienced health team, for two main reasons. First, the use of contraceptives was significantly lower in patients evaluated by the inexperienced health team. Second, this variable was not significantly associated with the report of ADRs in the logistic regression model.

The number of women of reproductive age was similar in both groups; contraceptive measures are required during treatment because the teratogenic effects of BZN are unknown. Therefore, the high proportion of women using contraceptive measures in the experienced health team indicates that the national guidelines were respected. This is the same case for lactating women, because although national guidelines have not been updated, recent studies have shown that the percentage of BZN in breast milk is negligible, and therefore lactation is allowed under treatment. Again, this shows that the experienced team had more knowledge.

Overall, during the first year of implementation of the extension program, ADRs were reported in $30.4 \%(62 / 204)$ of patients. This percentage is lower than the ones reported for $\mathrm{CD}$ patients 16-58 years old $(57.1 \%$ to $87.5 \%)(10,11)$ and for $C D$ pediatric patients 10 days to 19 years old (41.1\%) (9). Differences in the patients' age and BZN dosage 
between this program and the compared studies may explain the lower percentage observed. Similar percentages were reported by Viotti et al. (2009) in CD patients $9-66$ years old $(30.0 \%)$ and $30-50$ years old $(33.0 \%)$, although these studies considered a shorter treatment period compared to this program (30 versus 60 days respectively) (18).

The increase of ADR reporting frequency by age group (Table 4) is in accordance with the literature data showing that the incidence of BZN ADRs increases with age $(6,9,19)$. The highest frequency in this study was reported in patients older than 50 years $(42.9 \%)$, an age group for which it has been suggested that the risk of drug toxicity during anti-trypanosomal treatment may be higher compared to younger adults (6).

Another noteworthy finding was the fact that all treatment discontinuations (nine) occurred in patients followed by the health team with no previous experience. One possible explanation for this result is that experienced members were more likely to recognize the role of antihistamines in the control of BZN-related ADRs and, consequently, to provide patients with instructions for their use. In turn, this would have improved ADR control in patients followed by the experienced team and reduced treatment discontinuations. In addition, the lack of experience with BZN-related ADRs may have led inexperienced members to suspend treatment due to ADRs that did not represent a cause for interruption.

Overall, $2.9 \%$ of patients had to discontinue treatment due to ADRs, a lower percentage than the one reported for CD children 10 days to 19 years old (6.5\%) (9) and for CD patients 16-58 years old $(9.5 \%$ to $25.0 \%)(10,11)$.

The results from this study encourage the authors to recommend medical schools from endemic countries to give more training in $\mathrm{CD}$ diagnosis and treatment and to advise health authorities to equip PHCCs with basic technology and well-trained human resources. Most patients in the early onset of the disease could be diagnosed and treated at the primary care level.

Additional research on the influence of experience in BZN administration and the report of ADRs is advised. If, as suggested by these findings, there is an association between the two, the reporting of ADRs should decrease over time as health team members become more experienced. Further studies should aim to confirm this hypothesis.

\section{Limitations}

Along with level of experience in BZN administration to $\mathrm{CD}$ patients, other variables related to health team members are frequently associated with the reporting of ADRs and may have influenced the likelihood of ADR reporting during this program. These include gender, patient load, and academic background $(20,21)$. Because information on these variables was not collected in this program, it was not possible to compare the experienced and inexperienced health team members in terms of these features or assess whether they influenced the report of ADRs.

\section{REFERENCES}

1. Chagas C. Nova espécie mórbida do homem, produzida por um tripanossomo Trypanosoma cruzi. Braz Med. 1909; XXIII:16.

2. Chagas C. Nova tripanossomíase humana: estudos sobre a morfologia e o ciclo evolutivo do Schizotrypanum cruzi n. gen., n. sp., agente etiológico de nova entidade mórbida do homem. Mem Inst Oswaldo Cruz. 1909;1(2):159-218.

3. Sperandio da Silva GM, Mediano MFF, Alvarenga Americano do Brasil PE, da Costa Chambela M, da Silva JA, de Sousa AS, et al. A clinical adverse drug reaction prediction model for patients with chagas disease treated with benznidazole. Antimicrob Agents Chemother. 2014;58(11):6371-7. doi: 10.1128/AAC.02842-14.

4. Marin-Neto JA, Rassi A Jr, Avezum A Jr, Mattos AC, Rassi A, Morillo CA, et al.
The BENEFIT trial: testing the hypothesis that trypanocidal therapy is beneficial for patients with chronic Chagas heart disease. Mem Inst Oswaldo Cruz. 2009; 104 Suppl 1:319-24. doi: 10.1590/S007402762009000900042.

5. Pan American Health Organization. Estimación cuantitativa de la enfermedad de Chagas en las Américas. Washington: PAHO; 2016. Available from: http:// docplayer.es/12058322-Estimacion-cuantitativa-de-la-enfermedad-de-chagasen-las-americas.html Accessed on 21 September 2016.

6. Bern C, Montgomery SP, Herwaldt BL, Rassi A Jr, Marin-Neto JA, Dantas RO, et al. Evaluation and treatment of chagas disease in the United States: a systematic review. JAMA. 2007;298(18):2171-81. doi: 10.1001/jama.298.18.2171.
In addition, BZN treatment compliance was not evaluated and may have affected the incidence of ADRs.

\section{Conclusions}

The level of experience in BZN administration to $C D$ patients is significantly associated with the report of ADRs to treatment: health team members with no previous experience tend to report more ADRs. Reporting of ADRs also increases with patient age, regardless of health provider experience. Most patients with early-onset CD could be diagnosed and treated in primary care settings. Health authorities should ensure PHCCs have personnel experienced in BZN administration, and medical schools in endemic countries should increase training in CD diagnosis and treatment.

Acknowledgments. The authors thank the authorities from the Secretary of Health of La Plata (Buenos Aires Province) for allowing them to review and analyze medical records of patients followed in their centers, and all of the health team members for their collaboration.

Funding. This study was supported by Fundación Mundo Sano (Buenos Aires).

\section{Conflicts of interest. None.}

Disclaimer. Authors hold sole responsibility for the views expressed in the manuscript, which may not necessarily reflect the opinion or policy of the RPSP/ $P A J P H$ or the Pan American Health Organization (PAHO).
7. Pinazo MJ, Guerrero L, Posada E, Rodríguez E, Soy D, Gascon J. Benznidazole-related adverse drug reactions and their relationship to serum drug concentrations in patients with chronic chagas disease. Antimicrob Agents Chemother. 2013;57(1):390-5. doi: 10.1128/ AAC.01401-12.

8. Ministerio de Salud (AR). Guías para la atención al paciente infectado con Trypanosoma cruzi (enfermedad de Chagas). Buenos Aires: MSAL; 2012. Available from: http://www.fac.org.ar/ neuquen/cientifica/Guias_chagas_2012.pdf

9. Altcheh J, Moscatelli G, Moroni S, GarciaBournissen F, Freilij H. Adverse events after the use of benznidazole in infants and children with Chagas disease. Pediatrics. 2011;127(1):e212-8. doi: 10.1542/peds. 2010-1172. 
10. Pinazo MJ, Muñoz J, Posada E, LópezChejade P, Gállego M, Ayala E, et al. Tolerance of benznidazole in treatment of Chagas' disease in adults. Antimicrob Agents Chemother. 2010;54(11):4896-9. doi: 10.1128/AAC.00537-10.

11. de Pontes VM, Souza Júnior AS, Cruz FM, Coelho HL, Dias AT, et al. Reações adversas em pacientes com doença de Chagas tratados com benzonidazol, no Estado do Ceará. Rev Soc Bras Med Trop. 2010;43(2):182-7. doi: 10.1590/S003786822010000200015

12. Rassi A Jr, Rassi A, Marcondes de Rezende J. American trypanosomiasis (Chagas disease). Infect Dis Clin North Am. 2012; 26(2):275-91. doi: 10.1016/j.idc.2012.03.002.

13. Rassi A Jr, Rassi A, Marin-Neto JA. Chagas disease. Lancet. 2010;375(9723):1388-402. doi: 10.1016/S0140-6736(10)60061-X.

14. Angheben A, Giaconi E, Menconi M, Casazza G, Najajreh M, Anselmi M, et al. Reactivation of Chagas disease after a bone marrow transplant in Italy: first case report. Blood Transfus. 2012;10(4):542-4. doi: 10.2450/2012.0015-12.
15. Lenardòn $M$, Orsini $P$, Chopita $M$, Ramos $\mathrm{P}$, Cruz A, Crivaro F, et al. Chagas in a nonendemic area: first level health care. Lights and shadows. PEAH - Policies for Equitable Access to Health [Internet]. Available from: http://www.peah.it/2014/ 11 / chagas-in-a-non-endemic-area-firstlevel-health-care-lights-and-shadows / Accessed on 29 September 2016.

16. Bulla D, Luquetti A, Sánchez M, Estani SS, Salvatella R. Decálogo básico de la atención de la enfermedad de Chagas a nivel primario. Rev Chil Infectol. 2014;31(5):588-9. doi: 10.4067/S0716-10182014000500011.

17. Ministerio de Salud (AR). Guía para investigaciones en salud humana. Edición 2011. Buenos Aires: MSAL; 2011. Available from: http://www.msal.gov.ar/dis/wp-content/ uploads/sites/11/2016/06/Guia_en_ baja.pdf

18. Viotti R, Vigliano C, Lococo B, Alvarez MG, Petti M, Bertocchi G, et al. Side effects of benznidazole as treatment in chronic Chagas disease: fears and realities. Expert Rev Anti Infect Ther. 2009;7(2):157-63. doi: 10.1586/14787210.7.2.157.
19. Forsyth CJ, Hernandez S, Olmedo W, Abuhamidah A, Traina MI, Sanchez DR, et al. Safety profile of nifurtimox for treatment of chagas disease in the United States. Clin Infect Dis. 2016;63(8):1056-62. doi: $10.1093 / \mathrm{cid} / \mathrm{ciw} 477$.

20. Figueiras A, Tato F, Fontaiñas J, GestalOtero JJ. Influence of physicians' attitudes on reporting adverse drug events: a casecontrol study. Med Care. 1999;37(8): 809-14.

21. Herdeiro MT, Polonia J, Gestal-Otero JJ, Figueiras A. Factors that influence spontaneous reporting of adverse drug reactions: a model centralized in the medical professional. J Eval Clin Pract. 2004;10(4): 483-9. doi.org/10.1111/j.1365-2753.2003. 00456.x.

Manuscript submitted 23 June 2017. Revised version accepted for publication on 23 October 2017.

RESUMEN El presente estudio evaluó y comparó el seguimiento y la notificación de reacciones adversas medicamentosas (RAM) en pacientes con enfermedad de Chagas tratados con benznidazol por dos equipos de salud con diferentes niveles de experiencia,

Notificación de las reacciones adversas al benznidazol: ¿importa la pericia médica? mediante el uso de los expedientes médicos de 204 pacientes que participaron en el primer año de un programa de salud pública ampliado para la detección de casos de enfermedad de Chagas y su tratamiento, realizado en los 46 centros de atención primaria de salud del distrito de La Plata (Buenos Aires) en el 2014. Ambos equipos tenían experiencia en la atención de pacientes con enfermedad de Chagas, estaban capacitados en la administración de benznidazol e incluían médicos experimentados, pero uno de los equipos nunca había usado benznidazol, mientras que el otro tenía tres años de experiencia por su participación en el proyecto piloto del programa. Los pacientes con pruebas serológicas positivas para la enfermedad de Chagas recibieron $5 \mathrm{mg} / \mathrm{kg} /$ día de benznidazol durante 60 días. La mediana de edad de los pacientes era de 35 años y 84,3\% eran mujeres. Hubo una diferencia estadísticamente significativa entre el número de reacciones adversas medicamentosas notificadas por el equipo de salud experimentado y el equipo sin experiencia (18 y 44, respectivamente; $P<0.001$ ). Tanto la experiencia de los equipos de salud en la administración de benznidazol a los pacientes con enfermedad de Chagas como la duración del tratamiento se asociaron significativamente con la notificación de reacciones adversas medicamentosas (razones de posibilidades ajustadas, 0,340; intervalo de confianza de 95\% [IC]: 0,177-0,652; y 0,967, IC: 0,942-0,993, respectivamente). La notificación de reacciones adversas medicamentosas aumentó a mayor edad de los pacientes; la frecuencia máxima $(42,9 \%)$ se observó en las personas mayores de 50 años. Todas las interrupciones del tratamiento (nueve) fueron en pacientes atendidos por el equipo de salud sin experiencia. El nivel de experiencia en la administración de benznidazol a los pacientes con enfermedad de Chagas mostró una asociación significativa e inversa con la frecuencia de notificación de reacciones adversas medicamentosas: los miembros del equipo de salud sin experiencia tendieron a notificar más reacciones.

Palabras clave
Enfermedad de Chagas; atención primaria de salud; efectos colaterales y reacciones adversas relacionados con medicamentos; salud pública; Argentina; América Latina. 
RESUMO Neste estudo foram analisados e comparados dados notificados de reação adversa medicamentosa e de acompanhamento de pacientes com doença de Chagas tratados com benznidazol (BZN) por dois grupos de profissionais da saúde com níveis de expe-

Notificação de reações adversas ao benznidazol: experiência médica faz diferença?

Palavras-chave riência distintos. Os dados foram obtidos dos prontuários médicos de 204 pacientes que participaram do primeiro ano de um programa expandido de saúde pública para detecção de casos e tratamento da doença de Chagas implantado nas 46 unidades básicas de saúde do distrito de La Plata em Buenos Aires, Argentina, em 2014. Ambos os grupos eram formados por médicos mais graduados e profissionais com experiência na conduta de pacientes com doença de Chagas e capacitados em administrar $\mathrm{BZN}$, porém um dos grupos era inexperiente em administrar BZN enquanto o outro contava com experiência de três anos por ter participado do projeto-piloto do programa. Os pacientes com sorologia positiva para doença de Chagas foram tratados com $5 \mathrm{mg} / \mathrm{kg} /$ dia de BZN por 60 dias. A mediana de idade foi 35 anos e 84,3\% dos pacientes eram do sexo feminino. Verificou-se uma diferença estatisticamente significativa no número de reações adversas medicamentosas notificadas pelo grupo experiente em relação ao grupo inexperiente (18 vs. 44 , respectivamente; $P<0.001)$. Ter experiência em administrar BZN aos pacientes com doença de Chagas e a duração do tratamento foram fatores significativamente associados à notificação de reação adversa medicamentosa (razão de chances ajustada [aOR] 0,340, intervalo de confiança de 95\% [IC 95\%] 0,177-0,652 e aOR 0,967, IC 95\% 0,942-0,993, respectivamente). A notificação de reação adversa medicamentosa aumentou de acordo com a idade do paciente, ocorrendo com maior frequência (42,9\%) nos pacientes acima de 50 anos. Os 9 casos de interrupção do tratamento ocorreram em pacientes acompanhados pelo grupo inexperiente. O nível da experiência em administrar $\mathrm{BZN}$ aos pacientes com doença de Chagas teve uma associação significativa e inversa com a frequência de notificação de reação adversa medicamentosa: os integrantes do grupo inexperiente tenderam a notificar mais.

Doença de Chagas; atenção primária à saúde; efeitos colaterais e reações adversas relacionados a medicamentos; saúde pública; Argentina; América Latina. 